\title{
Dopamine Genetics: Substance Use Disorders vs. Parkinson's Disease
}

\author{
Carl Lin Z. ${ }^{1}$, Hall F.S. ${ }^{2}$, Bell R.L. ${ }^{3}$ \\ ${ }^{1}$ Laboratory of Psychiatric Neurogenomics at McLean Hospital, and Department of Psychiatry, \\ Harvard Medical School, MA, USA \\ ${ }^{2}$ Department of Pharmacology and Experimental Therapeutics, College of Pharmacy and Pharmaceutical Sciences, \\ University of Toledo, Toledo, OH, 43537, USA \\ ${ }^{3}$ Department of Psychiatry, Institute of Psychiatric Research, Indiana University School of Medicine, \\ Indianapolis, IN, 46202, USA
}

\begin{abstract}
Summary. It is established that Substance use disorders (SUDs) and Parkinson's Disease (PD) among many other neuropsychiatric disorders are dopamine (DA)-related brain disorders with strong heritability. However, it is unclear whether DA-associated genetic risks share commonality across these disorders. This study utilizes the Genotype and Phenotype Database ( $\mathrm{dbGaP})$, by downloading related genome-wide association studies (GWAS) for individual genotype/phenotypes. According to our results DA pathways are significantly implicated in the genetic etiology of both SUDs and PD but much more in the former. Epistatic effects may represent a major portion of missing heritability observed in current main effect-oriented GWAS analyses.

Keywords: disease-specific, epistasis, genetic etiology, missing heritability, neuropsychiatric disorders, pathways.
\end{abstract}

\section{Генетика дофаминэргической системы: сравнение аддикций и болезни Паркинсона}

\author{
Карл Лин 3. ${ }^{1}$, Холл Ф.С. ${ }^{2}$, Бэлл Р.Л. ${ }^{3}$ \\ ${ }^{1}$ Лаборатория Психиатрической Нейрогеномики госпиталя МакЛин и кафедра психиатрии, \\ Медицинская школа Гарварда, Массачусетс, США \\ ${ }^{2}$ Отделение Фармакологии и Экспериментальной терапии, колледж фармакологии и фармацевтических наук, \\ Университет Толедо, Толедо, Огайо, 43537, США \\ ${ }^{3}$ Отделение психиатрии, Институт психиатрических исследований, Университетская медицинская школа \\ Индианы, Индианаполис, Индиана, 46202, США
}

Резюме. Установлено, что расстройства, связанные с употреблением психоактивных веществ (SUDs) и болезнь Паркинсона (PD), среди многих других психоневрологических расстройств являются связанными с дофамином (DA) расстройствами головного мозга с высоким уровнем наследуемости. Тем не менее, неясно, имеют ли эти заболевания общие механизмы формирования генетических рисков. В этом исследовании используется база данных генотипов и фенотипов (dbGaP) путем загрузки связанных исследований геномных ассоциаций (GWAS) для отдельных генотипов / фенотипов. Согласно нашим результатам, дофаминэргическая нейромедиация в значительной степени вовлечена в генетическую этиологию как SUD, так и PD, но гораздо больше в первом случае.

Ключевые слова: болезнь-специифичный, эпистаз, генетическая этиология, пропущенная наследственность, нейропсихиатрические заболевания, пути.

\section{BACKGROUND}

$\mathrm{S}$ ubstance use disorders (SUDs) are the leading cause of chronic diseases, generating enormous global economic burden [1-4] and are a major public health concern.[5-9] Unfortunately, there are few clinically accepted medications to treat SUDs.[4] It is established that SUDs and Parkinson's Disease (PD) among many other neuropsychiatric disorders are dopamine(DA)-related brain disorders with strong heritability.[10] However, it is unclear whether DAassociated genetic risks share commonality across these disorders.

\section{AIM}

Determine whether these neuropsychiatric disorders have common risks in DA-associated genes, including DA synthesis (2 genes), metabolism (2 genes), receptors (DRs, 5 genes), monoamine transporters
(5 genes), an uptake modulator (alpha-synuclein: SNCA), and transcription factors (7 genes) [11, 12].

\section{MATERIALS \& METHODS}

This study utilizes the Genotype and Phenotype Database (dbGaP), by downloading related genomewide association studies (GWAS) for individual genotype/phenotypes. First, genomic controlling was performed to ensure unrelatedness among subjects[13]; secondly, linkage-based imputation procedures were conducted to capture genotypes for these 22 DA system genes including serotonin and norepinephrine transporters' genes as controls; thirdly, association analyses for main effects and Logistic regressionbased epistasis analyses for intergenic effects on neuropsychiatric etiologies; and, finally meta-analyses of these association results. Genetic manipulations of gene activity in animal models were carried out to determine causality of these genetic associations. 


\section{RESULTS}

Overall three SUD GWAS datasets and three PD datasets were utilized for the meta-analysis. After genomic and quality control, data from more than 6500 unrelated subjects with each disease were used in the analysis.

Specifically data from four SUD [12] cohorts were obtained from the three datasets: Collaborative Study on the Genetics of Alcoholism (COGA, dbGaP accession\#: phs000125.v1.p1), Study of Addiction: Genetics and Environment (SAGE, polysubstance abuse but mainly with cigarette smoking, dbGaP accession\#: phs000092.v1.p1), and the Australian twin-family study of alcohol use disorder (OZALC, dbGaP accession\#: phs000181.v1.p1). After COGA data quality control (QC), data from the US Caucasians of European (EA) descent and African Americans (AA) were split into these 2 separate ethnic cohorts. Individuals found in both the COGA and SAGE studies, were removed from the SAGE datasets. The OZALC study used family genotype but only unrelated individuals were extracted for the purpose of epistasis analysis. After QC, data from 6,596 subjects remained: 1,368 from COGA_EA, 753 from COGA_AA, 2,063 from the OZALC study, and 2,412 from the SAGE study.

Data from three $\mathrm{PD}[14]$ cohorts were screened [phg000126.v1.p1 (CIDR), phs000089.v3.p2 (NINDS), and phs000196.v2.p1 (NGRC)]. Cohort composition included CIDR (900 cases and 867 controls); NINDS (940 cases and 801 controls); and NGRC (2013 cases and 1995 controls). After QC, the CIDR dataset included 770 cases and 783 controls; the NINDS dataset included 716 cases and 673 controls; and the NGRC dataset included 2000 cases and 1986 controls, for a total of 6,533 unrelated subjects.
After initial analyses, only one of the 22 genes, SNCA, showed a significant main effect for PD which is consistent with the established literature. After Bonferroni corrections, none of the target genes resulted in a significant main effect for SUDs. However, epistasis analysis uncovered extensive and significant association signals between gene variants and SUDs or, to less extent, PD.

For SUDs, the strongest significant interaction was SNCA with the developmentally expressed vesicular monoamine transporter 1 gene SLC18A1 and our recently discovered TFs. The greatest number of significant interactions were between the DA transporter gene SLC6A3 and 21 of the 22 genes including two DR genes, DRD3 and DRD5. For PD, DRD3 interacted with the tyrosine hydroxylase gene $\mathrm{TH}$ and the dopadecarboxylase gene DDC; SLC6A3 interacted with 6 of the 22 target genes. Interestingly, the interaction between DRD3 and the NET gene (SLC6A2) was implicated in both diseases. Importantly, the significant association between SLC6A3 and SUD was confirmed by findings from mouse modeling.[14]

\section{CONCLUSIONS}

DA pathways are significantly implicated in the genetic etiology of both SUDs and PD but much more in the former. Epistatic effects may represent a major portion of missing heritability observed in current main effect-oriented GWAS analyses.

\section{Acknowledgements}

We thank NIH for granting ZL access to dbGaP, under project \#1542: "Functional genomics of dopamine-related diseases". This work was supported by the U.S. National Institutes of Health grants DA021409, AA026663 (ZL), AA015512 and AA013522 (RLB).

\section{References}

1. Rehm J, Mathers C, Popova S, Thavorncharoensap $M$, Teerawattananon Y, Patra J. Global burden of disease and injury and economic cost attributable to alcohol use and alcohol-use disorders. Lancet. 2009;373(9682):2223-33. Epub 2009/06/30. doi: 10.1016/s0140-6736(09)60746-7. PubMed PMID: 19560604.

2. Bauer UE, Briss PA, Goodman RA, Bowman BA. Prevention of chronic disease in the 21st century: elimination of the leading preventable causes of premature death and disability in the USA. Lancet. 2014;384(9937):45-52. Epub 2014/07/06. doi: 10.1016/s0140-6736(14)60648-6. PubMed PMID: 24996589.

3. Forouzanfar $M H$, Alexander $L$, Anderson $H R$, Bachman VF, Biryukov S, Brauer M, et al. Global, regional, and national comparative risk assessment of 79 behavioural, environmental and occupational, and metabolic risks or clusters of risks in 188 countries, 1990-2013: a systematic analysis for the Global Burden of Disease Study 2013. Lancet. 2015;386(10010):2287-323. Epub 2015/09/15. doi: 10.1016/s0140-6736(15)00128-2. PubMed PMID: 26364544; PubMed Central PMCID: PMCPmc4685753.

4. Manthey J, Shield KD, Rylett M, Hasan OSM, Probst C, Rehm J. Global alcohol exposure between 1990 and 2017 and forecasts until 2030: a modelling study. Lancet. 2019;393(10190):2493-502. Epub 2019/05/12. doi: 10.1016/s0140-6736(18)32744-2. PubMed PMID: 31076174.

5. Patel V, Chisholm D, Parikh R, Charlson FJ, Degenhardt L, Dua T, et al. Addressing the burden of mental, neurological, and substance use disorders: key messages from Disease Control Priorities, 3rd edition. Lancet. 2015. Epub 2015/10/12. doi: 10.1016/s0140-6736(15)00390-6. PubMed PMID: 26454360.

6. Global, regional, and national incidence, prevalence, and years lived with disability for 354 diseases and injuries for 195 countries and territories, 1990-2017: a systematic analysis for the Global Burden of Disease Study 2017. Lancet. 2018;392(10159):1789-858. Epub 2018/11/30. 
doi: 10.1016/s0140-6736(18)32279-7. PubMed PMID: 30496104; PubMed Central PMCID: PMCPMC6227754.

7. Aldridge RW, Story A, Hwang SW, Nordentoft $M$, Luchenski SA, Hartwell G, et al. Morbidity and mortality in homeless individuals, prisoners, sex workers, and individuals with substance use disorders in high-income countries: a systematic review and meta-analysis. Lancet. 2018;391(10117):241-50. Epub 2017/11/16. doi: 10.1016/s0140-6736(17)31869-x. PubMed PMID: 29137869; PubMed Central PMCID: PMCPMC5803132.

8. Global, regional, and national age-sex-specific mortality for 282 causes of death in 195 countries and territories, 1980-2017: a systematic analysis for the Global Burden of Disease Study 2017. Lancet. 2018;392(10159):1736-88. Epub 2018/11/30. doi: 10.1016/s0140-6736(18)32203-7. PubMed PMID: 30496103; PubMed Central PMCID: PMCPMC6227606.

9. Zhou M, Wang H, Zeng X, Yin P, Zhu J, Chen W, et al. Mortality, morbidity, and risk factors in China and its provinces, 1990-2017: a systematic analysis for the Global Burden of Disease Study 2017. Lancet. 2019. Epub 2019/06/30. doi: 10.1016/s01406736(19)30427-1. PubMed PMID: 31248666.

10. Goldman D, Oroszi G, Ducci F. The genetics of addictions: uncovering the genes. Nature reviews
Genetics. 2005;6(7):521-32. Epub 2005/07/05. doi: 10.1038/nrg1635. PubMed PMID: 15995696.

11. Zhao Y, Yu J, Zhao J, Chen X, Xiong N, Wang $T$, et al. Intragenic Transcriptional cis-Antagonism Across SLC6A3. Molecular neurobiology. 2018. Epub 2018/09/28. doi: 10.1007/s12035-018-13575. PubMed PMID: 30259411.

12. Liu $K, Y$, J, Zhao J, Zhou Y, Xiong N, Xu J, et al. (AZI2)3'UTR Is a New SLC6A3 Downregulator Associated with an Epistatic Protection Against Substance Use Disorders. Molecular neurobiology. 2018;55(7):5611-22. Epub 2017/10/07. doi: 10.1007/ s12035-017-0781-2. PubMed PMID: 28983843; PubMed Central PMCID: PMCPMC5886844.

13. Anderson CA, Pettersson FH, Clarke GM, Cardon LR, Morris AP, Zondervan KT. Data quality control in genetic case-control association studies. Nature protocols. 2010;5(9):1564-73. Epub 2010/11/19. doi: 10.1038/nprot.2010.116. PubMed PMID: 21085122; PubMed Central PMCID: PMCPmc3025522.

14. Bahi A, Dreyer JL. No effect of sex on ethanol intake and preference after dopamine transporter (DAT) knockdown in adult mice. Psychopharmacology. 2018. Epub 2018/12/13. doi: 10.1007/ s00213-018-5144-9. PubMed PMID: 30539268.

\section{Сведения об авторах}

Carl Lin Z. - Laboratory of Psychiatric Neurogenomics at McLean Hospital, and Department of Psychiatry, Harvard Medical School, MA, USA

Hall F.S. - Department of Pharmacology and Experimental Therapeutics, College of Pharmacy and Pharmaceutical Sciences, University of Toledo, Toledo, OH, 43537 USA

Bell R.L. - Department of Psychiatry, Institute of Psychiatric Research, Indiana University School of Medicine, Indianapolis, IN, 46202, USA 